\title{
Review
}

\section{Nigella sativa (black seed) safety: an overview}

\author{
Habibeh Mashayekhi-Sardoo ${ }^{1, \ldots \oplus}$, Ramin Rezaee ${ }^{23, \pm \oplus}$, Gholamreza Karimi ${ }^{1,4 * * \oplus}$
}

\begin{abstract}
Nigella sativa (commonly known as black seed or black cumin), from the family Ranunculaceae, is a plant that grows in countries bordering the Mediterranean Sea. This narrative review discusses the toxicological profile reported by short- to long-term studies that examined different extracts and oils of $N$. sativa seeds. Scientific databases including Web of Science, PubMed, Scopus, and Google Scholar were searched using appropriate keywords. LD $_{50}$ for administered N. sativa seed fixed oil varied from $28.8 \mathrm{~mL} / \mathrm{kg}$ to $3,371 \mathrm{mg} / \mathrm{kg}$ in mice, while $21 \mathrm{~g} / \mathrm{kg}$ of aqueous, methanol, and chloroform extracts of $N$. sativa did not lead to any mortality. Subacute toxicity evaluations indicated that aqueous, methanol, and chloroform extracts of $N$. sativa at doses as high as $6 \mathrm{~g} / \mathrm{kg}$ do not produce toxicity. Investigation of chronic toxicity found that $2 \mathrm{~mL} / \mathrm{kg}$ of $N$. sativa fixed oil is slightly toxic. Cytotoxicity studies indicated that $N$. sativa chloroform and petroleum ether extracts are more cytotoxic than its other extracts. Although studies that assessed $N$. sativa toxicity generally introduced it as a safe medicinal herb, to draw a more definitive conclusion on its safety, more detailed studies must be conducted.
\end{abstract}

Keywords: alpha-hederin; carvacrol; 4-cymene; triterpenoid saponin; thymoquinone

Nigella sativa (N. sativa, Ranunculaceae family), commonly known as "black seed" or "black cumin," is a flowering plant that grows in countries bordering the Mediterranean Sea, and in Pakistan, India, and Iran [1]. The people of the Middle East and Southeast Asian countries have used N. sativa seeds to treat disorders, such as bronchitis, asthma, and inflammatory, infectious, and gastrointestinal diseases, and applied its oil to treat skin diseases such as boils and eczema [2]. N. sativa seeds play an important role in the traditional treatment of various diseases, especially fever, chronic headache, migraine, hypertension, and paralysis [3]. Additionally, the extracts of $N$. sativa are traditionally used as a laxative, intestinal antiprotozoal agent, and carminative [4].
In the past 2 decades, various pharmacological or medicinal aspects of $N$. sativa including its antibacterial [5], anticancer [6, 7], anti-inflammatory [8], antioxidant [9, 10], immunomodulatory [11], analgesic [12-14], diuretic [15, 16], antihypertensive [17], antidiabetic [18-20], neuroprotective [16], gastroprotective [21, 22], and hepatoprotective properties [23], have been reported. N. sativa has been used in clinical research for neurological disorders [24-26], hypertension $[27,28]$, hyperlipidemia $[29,30]$, obesity $[31,32]$, rheumatoid arthritis [33-35], lung disease [36], thyroid dysfunction [37], hepatitis [38], and male infertility [39].

The herbaceous plant contains fixed oil (FO, 36\%$38 \%$ ), carbohydrates, proteins, fiber, minerals, volatile oil

*Correspondence to: Gholamreza Karimi, Professor of Pharmaceutical Research Center, Institute of Pharmaceutical Technology, Mashhad University of Medical Sciences, Mashhad, PO Box 1365-91775, Iran, e-mail: KarimiG@mums.ac.ir \# These authors contributed equally to this work.

'Department of Pharmacodynamics and Toxicology, School of Pharmacy, Mashhad University of Medical Sciences, Mashhad 917794-8564, Iran ${ }^{2}$ Clinical Research Unit, Faculty of Medicine, Mashhad University of Medical Sciences, Mashhad 917794-8564, Iran

${ }^{3}$ Neurogenic Inflammation Research Center, Mashhad University of Medical Sciences, Mashhad 917794-8564, Iran

${ }^{4}$ Pharmaceutical Research Center, Institute of Pharmaceutical Technology, Mashhad University of Medical Sciences, Mashhad 917794-8564, Iran

DOpen Access. ๑ 2020 Mashayekhi-Sardoo et al., published by Sciendo. (cc)BY-NC-ND This work is licensed under the Creative Commons Attribution NonCommercial-NoDerivatives 4.0 License. 
$(0.2 \%)$, essential oil ( $0.4 \%-2.5 \%)$, alkaloids, coumarins, and saponins [40-42]. The main bioactive components of $N$. sativa seeds are thymoquinone, carvacrol, 4-cymene, pentacyclic triterpenoid saponins ( $\alpha$-hederin), and alkaloids (nigellicine, nigellicimine, nigellicimine- $N$-oxide, and nigellidine) $[43,44]$. Thymoquinone is the main and most abundant (27.8\%-57.0\%) compound of $N$. sativa seeds essential oil, and the other components, such as carvacrol (5.8\%-11.6\%), 4-cymene (7.1\%-15.5\%), 4-terpineol (2.0\%-6.6\%), $t$-anethole $(0.25 \%-2.3 \%)$, and longifolene $(1.0 \%-8.0 \%)$ exist at lower amounts $[45,46]$. Thymoquinone is also the major volatile component $(0.72 \%-21.03 \%)$ of $N$. sativa volatile oil and has shown several pharmacological activities related to oxidative stress [7, 20]. Figure 1 presents the main bioactive components of $N$. sativa $[43,44]$.

$N$. sativa seed extracts and its bioactive components are generally regarded as chemicals with low toxicity [43, 47] that have a wide margin of safety $[48,49]$. Nevertheless, the common structure of thymoquinone may cause oxidative stress and damage cellular macromolecules (DNA, lipids, and proteins) and signaling pathways, such as extracellular signalregulated kinase (ERK), protein kinase $\mathrm{C}(\mathrm{PKC})$ and Ras; however, it is postulated that coexistence of other components of $N$. sativa reduces thymoquinone toxicity [45, 50-52].
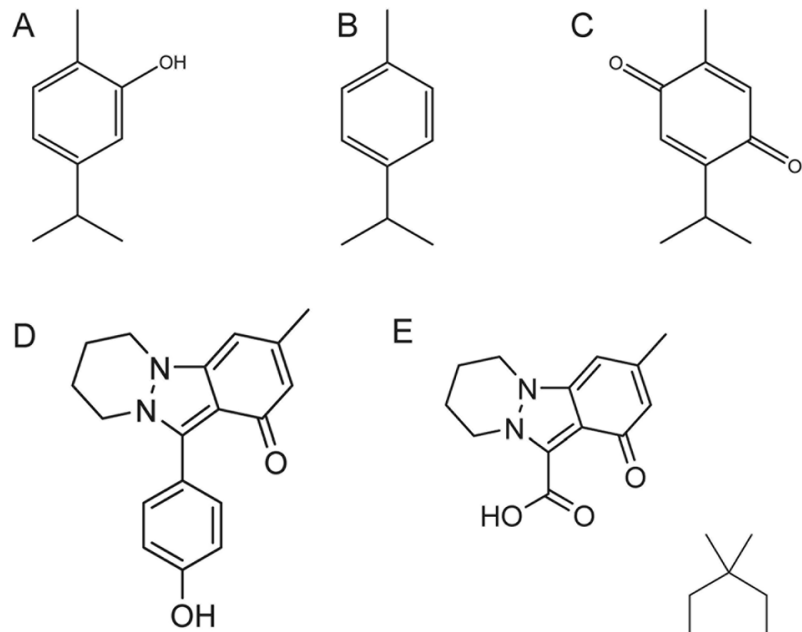

$E$<smiles>Cc1cc2n3n(c(C(=O)O)c-2c(=O)c1)CCCC3</smiles>

$\mathrm{F}$

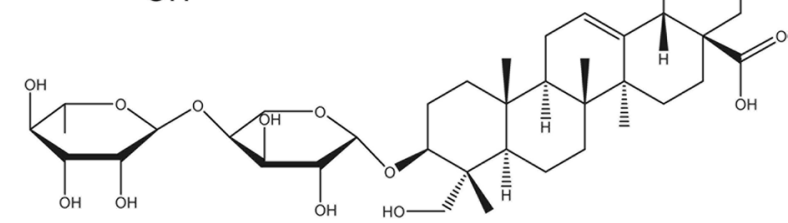

Figure 1. Main bioactive components of N. sativa: (A) carvacrol (5-isopropyl-2-methylphenol; National Center for Biotechnology Information. PubChem Database compound identification number [CID] 10364), (B) 4-cymene (4-isopropyltoluene; CID 7463), (C) thymoquinone (4-cymene-2,5-dione; CID 10281), (D) nigellidine (CID 136828302), (E) nigellicine (CID 11402337), and (F) $\alpha$-hederin (CID 73296).
Figure 2 presents various toxicities observed following exposure to $N$. sativa [49, 53-61].

The present narrative review discusses the toxicity and adverse effects of different extracts and oils obtained from $N$. sativa reported in animals, cell lines, and humans.

\section{Methods}

We conducted a literature search of scientific databases including Web of Science, PubMed, Scopus, and Google Scholar. In this search, the following string of keywords was used: "Nigella sativa" or "sativa" or "Nigella" or "black seed" or "black cumin" or "black cumins" or "thymoquinone" or "carvacrol" or "4-cymene" and "safety" or "toxicity" or "cytotoxicity" or "genotoxicity" and "acute" or "subacute" or "subchronic" or "chronic". The wild-card asterisk (*) was used to increase the scope of the search. The reference lists of discovered articles were also reviewed to identify reports that evaluated N. sativa toxicity published until March 2020. All studies that assessed the toxicity or reported adverse reactions of $N$. sativa following topical, parenteral, and oral treatment of experimental animals and humans and data from experiments done on cell lines, were included. All included studies were written in English. Review articles were not included.

\section{Discussion}

\section{Acute toxicity of $N$. sativa in animal studies}

The median lethal dose $(50 \%)\left(\mathrm{LD}_{50}\right)$ values of $N$. sativa seed volatile oil, fixed oil (prepared by hexane extraction), and aqueous extract in male Swiss albino (SWR) mice were calculated using a Litchfield and Wilcoxon method. Intraperitoneal administration of volatile oil, aqueous extract, and fixed oil of $N$. sativa has $\mathrm{LD}_{50}$ values of 1,853, 3,020, and $3,371 \mathrm{mg} / \mathrm{kg}$, respectively. Based on these data, authors attributed $N$. sativa toxicity to its volatile oil rather than aqueous extract and fixed oil [51].

Oral $(10,15,20,25,30,40$, and $50 \mathrm{~mL} / \mathrm{kg})$ or intraperitoneal $(0.25,0.5,1,2,3,4$, and $6 \mathrm{~mL} / \mathrm{kg})$ doses of $N$. sativa seeds fixed oil (prepared by hexane extraction) made in gum acacia $(5 \%)$, were given to male and female mice. Importantly, using thin-layer chromatography (TLC), the fixed oil was characterized and it contained myristic, palmitic, stearic, oleic, linoleic, linolenic, and arachidic acids; triterpenes, and saponosides. For all doses, oral or intraperitoneal administration of $N$. sativa led to behavioral disorders and agitation followed 


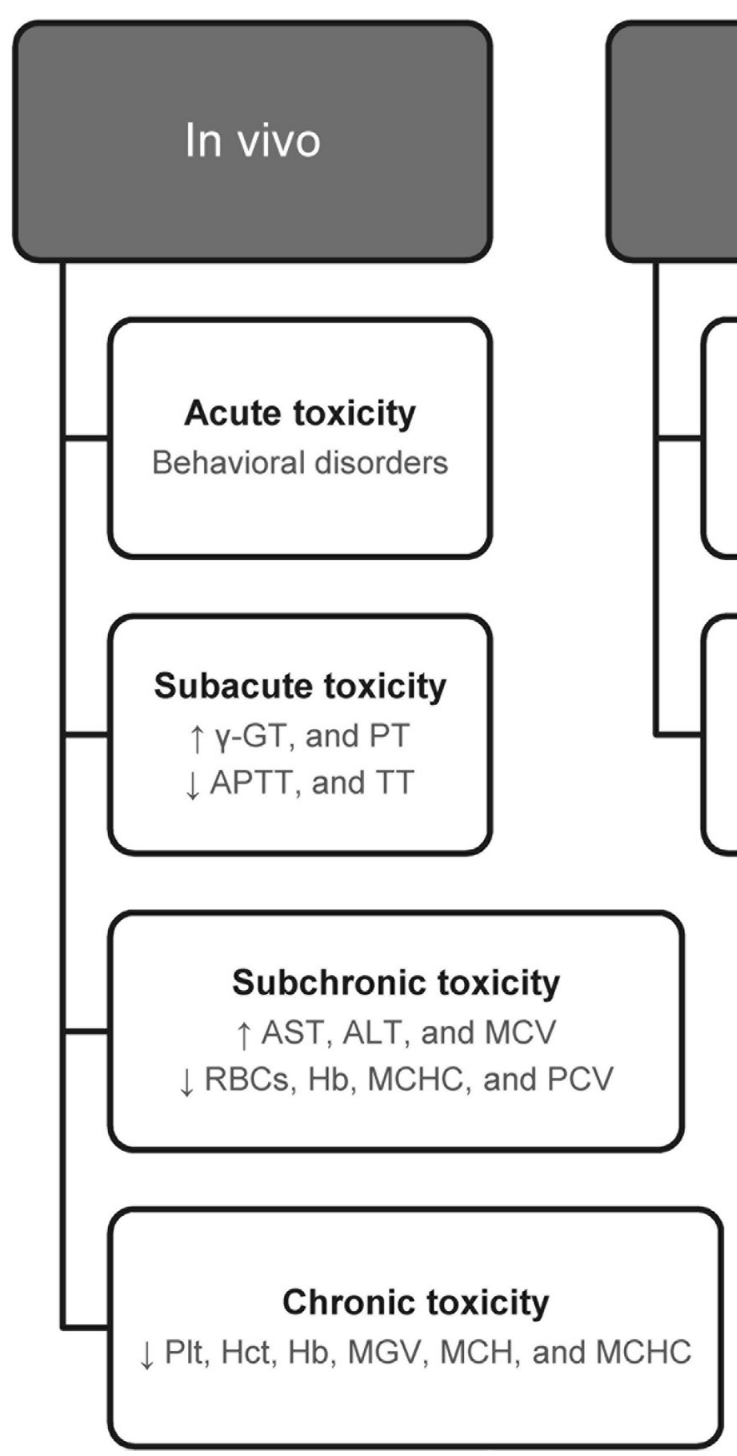

Figure 2. Various toxicities reported for N. sativa. Abbreviations: $\gamma$-GT, gamma-glutamyl transferase; ALP, alkaline phosphatase; ALT, alanine transaminase; AST, aspartate aminotransferase; PT, prolonged prothrombin time; APTT, activated partial thromboplastin time; TT, thrombin time; ATIII, antithrombin III; RBCs, red blood cells; $\mathrm{Hb}$, hemoglobin; $\mathrm{MCH}$, mean corpuscular hemoglobin; $\mathrm{MCHC}$, mean corpuscular hemoglobin concentration; PCV, packed cell volume; MCV, mean corpuscular volume; Plt, platelet; Hct, hematocrit; MGV, mean globular volume; PARP, poly(ADP-ribose) polymerase.

by sedation. Furthermore, $12 \mathrm{~h}$ after administration of $N$. sativa $(50 \mathrm{~mL} / \mathrm{kg}$ oral or $4 \mathrm{~mL} / \mathrm{kg}$ intraperitoneal), all animals died. In surviving mice, activity and growth were rapidly retrieved within 4-8 days after oil administration. This study indicated $\mathrm{LD}_{50}$ values of $28.8 \mathrm{~mL} / \mathrm{kg}$ body weight (bw) and $2.06 \mathrm{~mL} / \mathrm{kg}$ bw for oral and intraperitoneal FO, respectively, and also indicated that $N$. sativa fixed oil is of low toxicity and possesses a wide margin of safety [49].

$\mathrm{LD}_{50}$ values for aqueous, methanol, and chloroform extracts of $N$. sativa seeds following a single oral administration of 4 different doses $(6,9,14$, and $21 \mathrm{~g} / \mathrm{kg})$ of the extracts to mice, was evaluated, but zero mortality was observed. The preliminary analysis found neither mortality nor significant morbidity following treatment with the extracts. Therefore, aqueous, methanol, and chloroform extracts were found to be safe and exerted a wide margin of safety following acute exposure [4].

A more recent study reported zero mortality $\left(\mathrm{LD}_{50}\right.$ could not be calculated) following administration of $N$. sativa essential oil at the doses of $0.2,0.4,0.4,0.8,1 \mathrm{mg} / \mathrm{kg}$ to either sex of white Wistar rats and albino mice (NMRI); however, this study lacked a full characterization of the essential oil and only total flavonoid content in terms of quercetin was reported [62]. 
A summary of studies [4, 49, 51, 62] that examined $N$. sativa acute toxicity is presented in Table $\mathbf{1}$.

\section{Subacute toxicity of $\boldsymbol{N}$. sativa in animal studies}

To study subacute toxicity of cumin seeds, $10 \mathrm{~mL} / \mathrm{kg}$ aqueous extract of $N$. sativa seeds was administered orally to male Sprague Dawley rats for 14 days. In this study, the aqueous extract was not characterized. The results demonstrated a notable increase in gamma-glutamyl transferase $(\gamma$-GT) amounts, though serum levels of alkaline phosphatase (ALP) remained unchanged and histopathological examinations did not show any damage; possibly, the findings were affected by an ether anesthesia effect on the release of ALP [63]. Oral administration of $10 \mathrm{~mL} / \mathrm{kg} N$. sativa seed oil to rats and mice for $48 \mathrm{~h}$ caused neither death nor obvious toxicity [53].

Oral administration of $6 \mathrm{~g} / \mathrm{kg} /$ day of aqueous extract, and methanol and chloroform extracts of $N$. sativa seeds to male mice, for 14 consecutive days, did not affect plasma concentrations of ALP, alanine transaminase (ALT), or aspartate aminotransferase (AST). The pathological findings outlined only minor alterations in mice livers following treatment with these extracts. This study showed that even the 14-day administration of $N$. sativa seeds extracts has a wide margin of safety in mice [4].

Furthermore, 90, 180, 360, and $540 \mathrm{mg} / \mathrm{kg}$ of $N$. sativa seed mixed in a powder dough, was given orally for 1, 2, and 4 weeks to normal adult male albino rats. In this study, the authors did not present any information on the chemical composition of the mixture. $N$. sativa at the tested doses transiently altered both anticoagulant and coagulant profiles of rats. In this context, $N$. sativa markedly prolonged prothrombin time caused hyperfibrinogenemia and reduced activated partial thromboplastin time and thrombin time. Nevertheless, antithrombin III (ATIII) and AST levels remained unchanged while ALT and albumin levels significantly increased [54].

Powdered $N$. sativa seeds $(0.01,0.1$, and $1 \mathrm{~g} / \mathrm{kg} /$ day) administered for 28 days to male Sprague Dawley rats, did not affect the bodyweight of the rats, or serum AST and ALT levels compared with a control group. Histological examinations highlighted that 28-days treatment with these doses of $N$. sativa had no harmful impacts on liver tissue in the rats. However, no information on the composition of the seed powder was provided and the doses administered to rats were chosen based on human $N$. sativa consumption (viz., 2 g/d) [64].

Daily administration of $N$. sativa seeds aqueous extract (2, $6.4,21,33$, and $60 \mathrm{~g} / \mathrm{kg}$, orally) to mice for 6 weeks produced hepatotoxic effects (based on histopathological examinations) at doses $\geq 21 \mathrm{~g} / \mathrm{kg}$, but did not influence kidney tissue (in terms of urea and albumin levels). A high mortality rate was found following the administration of $60 \mathrm{~g} / \mathrm{kg}$ of the extract. The findings highlighted the safety of $N$. sativa at doses lower than $21 \mathrm{~g} / \mathrm{kg}$; however, the aqueous extract of the seeds was not characterized [65].

Although for centuries, a black seed and honey mixture (BSH) has used in traditional folk medicine, especially in Islamic countries because of its mention in the Hadith, its toxic effects are unclear. For this reason, a study was conducted to evaluate the effect of 14-day administration of 100, 500, 1,000, and $2,000 \mathrm{mg} / \mathrm{kg}$ doses of BSH to male Sprague Dawley rats and found an $\mathrm{LD}_{50}>2,000 \mathrm{mg} / \mathrm{kg}$. The findings showed no notable alteration in body weight, and differential leukocyte count, or abnormalities in liver and kidney histopathology; however, limitations of this study included a lack of mixture

Table 1. Acute toxicity of Nigella sativa in animal studies

\begin{tabular}{|c|c|c|c|c|}
\hline Substance/dose & Animals used & Observation period & $\mathbf{L D}_{50}$ & Reference \\
\hline $\begin{array}{l}\text { N. sativa seed } \\
V O, F O \text {, and } A E \text {, i.p. }\end{array}$ & SWR mice & $24 \mathrm{~h}$ & $\begin{array}{l}\text { AE: } 3,020 \mathrm{mg} / \mathrm{kg} \\
\text { VO: } 1,853 \mathrm{mg} / \mathrm{kg} \\
\text { FO: } 3,371 \mathrm{mg} / \mathrm{kg}\end{array}$ & [51] \\
\hline $\begin{array}{l}\text { N. sativa seed FO } \\
0.25,0.5,1,2,3,4 \text {, and } 6 \mathrm{~mL} / \mathrm{kg} \text {, i.p. }\end{array}$ & Both sexes of mice & 15 days & $2.06 \mathrm{~mL} / \mathrm{kg}$ & [49] \\
\hline $\begin{array}{l}\text { N. sativa seed FO } \\
10,15,20,25,30,40 \text {, and } 50 \mathrm{~mL} / \mathrm{kg} \text {, p.o }\end{array}$ & & & $28.8 \mathrm{~mL} / \mathrm{kg}$ & \\
\hline $\begin{array}{l}\text { N. sativa seeds } \\
A E, M E \text { and } C E \\
6,9,14 \text { and } 21 \mathrm{~g} / \mathrm{kg} \text {, p.o. }\end{array}$ & Both sexes of young virgin mice & 7 days & No mortality & [4] \\
\hline $\begin{array}{l}\text { N. sativa EO } \\
0.2,0.4,0.4,0.8,1 \mathrm{mg} / \mathrm{kg} \text {, p.o. }\end{array}$ & $\begin{array}{l}\text { Both sexes of white Wistar rats } \\
\text { and NMRI }\end{array}$ & Not specified & No mortality & [62] \\
\hline
\end{tabular}

$\mathrm{LD}_{50}$, lethal dose $50 \%$; VO, volatile oil; FO, fixed oil; $E \mathrm{O}$, essential oil; $\mathrm{AE}$, aqueous extract; $\mathrm{ME}$, methanol extract; $C E$, chloroform extract; SWR, male Swiss albino; NMRI, albino mice; i.p., intraperitoneal, p.o., per oral. 
characterization and histopathological assessment of only 2 organs [66].

Table 2 presents investigations [4, 53, 63-66] conducted to evaluate the subacute toxicity of $N$. sativa in animals.

\section{Subchronic toxicity of $\boldsymbol{N}$. sativa in animal studies}

Powdered N. sativa seeds (20 and $100 \mathrm{~g} / \mathrm{kg}$ ) were added to the diet of 7-day-old Hibro broiler chicks for 7 weeks. Administration of these doses of $N$. sativa seeds damaged the liver as reflected by increased AST and ALT levels and decreased albumin concentration and cholesterol levels in serum. Furthermore, $100 \mathrm{~g} / \mathrm{kg}$ of $N$. sativa decreased red blood cells (RBCs), hemoglobin level, mean corpuscular hemoglobin concentration, and packed cell volume despite increases in mean corpuscular volume levels. Together, the results suggested that a 7-week treatment with $N$. sativa seeds did not have a negative influence on growth, pathological features of the main organs, or biochemical/hematological profile of the animals [55].

N. sativa oil obtained from Cairo Chemical Industries Co. (15 and $25 \mathrm{mg} / \mathrm{kg}$ ) was administered to adult male albino rats for 1 month. However, no information on the chemical composition of the oil was noted. At the end of the experiment, histological changes were found in the cortex of the kidney and to a lesser extent, in hepatocytes in a dose-dependent manner. This study indicated that $N$. sativa oil (oil type not specified) must be used at appropriate doses [48].

Experiments [48, 55] that examined the subchronic toxicity of $N$. sativa are summarized in Table 3.

\section{Chronic toxicity of $\boldsymbol{N}$. sativa in animal studies}

$N$. sativa fixed oil (prepared by hexane extraction, $2 \mathrm{~mL} / \mathrm{kg}$ bw chosen based on the $\mathrm{LD}_{50}$ value obtained in an acute study) was orally given to Wistar-Kyoto rats for 12 weeks. Hematological

Table 2. Subacute toxicity of Nigella sativa in animal studies

\begin{tabular}{|c|c|c|c|c|c|}
\hline Substance/dose & Animals used & Exposure period & Observation period & Main results & Reference \\
\hline $\begin{array}{l}\text { N. sativa seeds AE } \\
10 \mathrm{~mL} / \mathrm{kg} \text {, p.o. }\end{array}$ & $\begin{array}{l}\text { Male Sprague } \\
\text { Dawley rats }\end{array}$ & 14 days & 30 days & $\begin{array}{l}\uparrow \text { Serum } \gamma \text {-GT and ALT levels. } \\
\text { Unchanged serum ALP levels and } \\
\text { histopathological examinations }\end{array}$ & {$[63]$} \\
\hline \multirow{2}{*}{$\begin{array}{l}\text { N. sativa seed oil } \\
10 \mathrm{~mL} / \mathrm{kg} \text {, p.o. }\end{array}$} & Rats & $48 \mathrm{~h}$ & Not specified & No toxicity & [53] \\
\hline & Mice & & & & \\
\hline $\begin{array}{l}\text { N. sativa seeds } \\
A E, M E \text {, and } C E \\
6 \mathrm{~g} / \mathrm{kg} \text {, p.o }\end{array}$ & $\begin{array}{l}\text { Both sexes of } \\
\text { young virgin mice }\end{array}$ & 14 days & Same 14 days & No toxicity wide margin of safety & [4] \\
\hline $\begin{array}{l}\text { N. sativa powder } \\
90,180,360 \text {, and } 540 \\
\mathrm{mg} / \mathrm{kg} \text {, locally }\end{array}$ & $\begin{array}{l}\text { Normal adult } \\
\text { male albino rats }\end{array}$ & 1,2 , and 4 weeks & Same 4 weeks & $\begin{array}{l}\text { Transient alterations in both } \\
\text { anticoagulant and coagulant } \\
\text { functions }\end{array}$ & [54] \\
\hline $\begin{array}{l}\text { N. sativa powder } 0.01,0.1 \text {, } \\
\text { and } 1 \mathrm{~g} / \mathrm{kg} / \text { day, p.o }\end{array}$ & $\begin{array}{l}\text { Male Sprague } \\
\text { Dawley rats }\end{array}$ & 28 days & Same 28 days & No toxicity & {$[64]$} \\
\hline $\begin{array}{l}\text { N. sativa } \mathrm{AE} \\
2,6.4,21,33 \text {, and } 60 \mathrm{~g} / \mathrm{kg} \text {, } \\
\text { orally), p.o }\end{array}$ & $\begin{array}{l}\text { Mus musculus } \\
\text { mice }\end{array}$ & 6 weeks & Same 6 weeks & $\begin{array}{l}21 \mathrm{~g} / \mathrm{kg} \text { : hepatotoxic } \\
60 \mathrm{~g} / \mathrm{kg} \text { : high mortality }\end{array}$ & {$[65]$} \\
\hline $\begin{array}{l}\text { BSH } \\
100,500,1,000, \text { and } \\
2,000 \mathrm{mg} / \mathrm{kg}, \text { p.o }\end{array}$ & $\begin{array}{l}\text { Male Sprague } \\
\text { Dawley rats }\end{array}$ & 14 days & 28 days & No toxicity & {$[66]$} \\
\hline
\end{tabular}

$\mathrm{AE}$, aqueous extract; $\mathrm{ME}$, methanol extract; $\mathrm{CE}$, chloroform extract; $\gamma$-GT, gamma-glutamyl transferase; ALP, alkaline phosphatase; ALT, alanine transaminase; BSH, black seed and honey mixture; i.p., intraperitoneal; p.o., per oral.

Table 3. Subchronic toxicity of Nigella sativa in animal studies

\begin{tabular}{llllll}
\hline Substance $/$ dose & Animals used & Exposure period & Observation period & Main results & Reference \\
\hline N. sativa seeds & 7-day-old Hibro broiler chicks & 7 weeks & Same 7 weeks & No toxicity \\
20 and $100 \mathrm{~g} / \mathrm{kg}$, p.o. & & & & \\
\hline
\end{tabular}

p.o., per oral. 
examinations showed significant decreases in leukocyte and platelet counts despite significant increases in hematocrit, hemoglobin, mean globular volume, mean corpuscular hemoglobin, and mean corpuscular hemoglobin concentration. No significant alterations were found in AST, ALT, ALP, and GGT levels and no histopathological damages were observed in the heart, kidneys, liver, and pancreas. The researchers suggested that $N$. sativa fixed oil has a wide margin of safety at therapeutic doses, but hematological impacts should be studied further [49].

Oral daily administration of $1 \mathrm{~mL} / \mathrm{kg}$ bw $N$. sativa seed fixed oil (prepared by hexane extraction) for 12 weeks to Wistar-Kyoto rats led to notable decreases in leukocyte and platelet counts. By contrast, hemoglobin and hematocrit levels were raised significantly. Nevertheless, serum levels of key hepatic enzymes (namely, AST, ALT, ALP, and GGT) did not change significantly relative to controls. Together, these results indicated mild toxicity for $N$. sativa seed FO. In this report, the authors did not specify the sex of the rats or the chemical composition of the fixed oil [56].

Studies $[49,56]$ that evaluated the chronic toxicity of $N$. sativa in animal models are presented in Table 4.

\section{Cytotoxic and genotoxic properties of N. sativa}

Various concentrations $(0.25,0.5$, and $1 \mu \mathrm{g} / \mathrm{mL})$ of $N$. sativa oil were tested for possible cytotoxicity in cultures of gingival fibroblasts, but no cytotoxicity of the oil against the fibroblasts was found [67]. This study was limited because it did not indicate which type of oil was examined.

Effects of ethanolic extract of $N$. sativa seeds on rat L6 muscle (L6myc) and human hepatocellular carcinoma (HepG2) cell lines were assessed using a 3-(4,5-dimethylthiazol-2-yl) -2,5-diphenyl tetrazolium bromide (MTT) and lactate dehydrogenase (LDH) assays. The effect of the extract on glucose transporter-4 (GLUT4) translocation to the plasma membrane of L6-GLUT4 myc cells was examined using an enzyme-linked immunosorbent assay (ELISA) method. The MTT and LDH assays results revealed cytotoxic effects of the extract at doses $>500 \mu \mathrm{g} / \mathrm{mL}$. The median effective concentration $\left(\mathrm{EC}_{50}\right)$ values for this extract were $>2,000 \mu \mathrm{g} /$ $\mathrm{mL}$ against L6myc and $>1,470 \mu \mathrm{g} / \mathrm{mL}$ HepG2 cell lines [68].

The influences of various doses of $N$. sativa ethanolic extract $(100,500$, and $1,000 \mu \mathrm{g} / \mathrm{mL})$ on viability and proliferation of nonstimulated and concanavalin $\mathrm{A}$ or phytohemagglutinin-stimulated isolated rat splenocytes were examined. Based on the results, $1,000 \mu \mathrm{g} / \mathrm{mL}$ of the ethanolic extract resulted in a marked decrease in cell viability and proliferation in both nonstimulated and stimulated cells [57].

Cytotoxic properties of the essential oil and different extracts (methanol, ether, petroleum ether, chloroform, and water) of $N$. sativa seeds were tested using a brine shrimp lethality assay; results revealed that chloroform and petroleum ether extracts were more toxic than the other extracts [69].

Cytotoxic effects of various concentrations (500, 250, 125 , and $62.5 \mu \mathrm{g} / \mathrm{mL}$ ) of $N$. sativa seeds volatile oil were tested against 5 human cancer cell lines namely, SCL, SCL-6, SCL-37'6, NUGC-4, and Kato-3, and 3T6 fibroblast line [70].

Cytotoxicity of petroleum ether and aqueous extracts of $N$. sativa for the human acute myeloid leukemia cell line (HL60) was tested, and it was found that petroleum ether extract is more toxic towards these cells having a lower halfmaximal inhibitory concentration $\left(\mathrm{IC}_{50}\right)$ [71]. Treatment of Huh7 human cells with $N$. sativa essential oil $(100 \mathrm{mg} / \mathrm{mL})$ did not affect cell viability [72].

$N$. sativa seed oil and its active component thymoquinone caused a decrease in the size and volume of glioblastoma multiforme (GBM) tumors in a xenograft mouse model. In cell lines including U-1242, U251, U-87, U-373, A172, and SNB19, $N$. sativa seed oil $(50-500 \mu \mathrm{g} / \mathrm{mL})$ and thymoquinone (1-20 $\mu \mathrm{M})$ inhibited, in a dose-dependent manner cell growth and colony formation in soft agar with an $\mathrm{IC}_{50}$ of $260 \mu \mathrm{g} / \mathrm{mL}$

Table 4. Chronic toxicity of Nigella sativa in animal studies

\begin{tabular}{|c|c|c|c|c|c|}
\hline Substance/dose & Animals used & Exposure period & Observation period & Main results & Reference \\
\hline $\begin{array}{l}\text { N. sativa FO } \\
2 \mathrm{~mL} / \mathrm{kg}, \text { p.o. }\end{array}$ & Wistar-Kyoto rats & 12 weeks & Same 12 weeks & $\begin{array}{l}\downarrow \text { Leukocyte and PIt } \\
\uparrow \mathrm{HCT}, \mathrm{Hb}, \mathrm{MGV}, \mathrm{MCH} \text {, and MCHC } \\
\text { No alteration in AST, ALT, ALP, and GGT levels } \\
\text { or histopathological features } \\
\text { Slight toxicity }\end{array}$ & [49] \\
\hline $\begin{array}{l}\text { N. sativa FO } \\
1 \text { mL/kg, p.o. }\end{array}$ & Wistar-Kyoto rats & 12 weeks & Same 12 weeks & $\begin{array}{l}\downarrow \text { Leukocyte and PIt } \\
\uparrow \mathrm{HCT}, \mathrm{Hb} \\
\text { No alteration in AST, ALT, ALP, and GGT levels } \\
\text { Slight toxicity }\end{array}$ & [56] \\
\hline
\end{tabular}

FO, fixed oil; AST, aspartate aminotransferase; Plt, platelet; Hct, hematocrit; Hb, hemoglobin; $\mathrm{MCH}$, mean corpuscular hemoglobin; MCHC, mean corpuscular hemoglobin concentration; MGV, mean globular volume; p.o. per oral. 
and $6 \mu \mathrm{M}$, respectively, activated the caspase- $9 / 3$ pathway and induced the cleavage of the death substrate poly(ADP-ribose) polymerase (PARP) [58].

Cytotoxicity, genotoxicity, and antigenotoxicity properties of aqueous extract of $N$. sativa seeds $(0.5,1,4,8,9$, and 18 $\mathrm{mg} / \mathrm{mL}$ ) from 3 diverse regions in Morocco were assessed in human C3A cells; the location where the herbs were collected, test system used, and other experimental parameters were important factors influencing the outcomes [73].

Apoptogenic effects of methanolic, n-hexane, and chloroform extracts of $N$. sativa seed were examined in HeLa cancer cells. The findings suggested that all of these extracts can induce apoptosis in cells as confirmed by western blotting, DNA fragmentation tests, and terminal transferase-mediated dUTP-digoxigenin-end labeling (TUNEL) assay [74].
Potential antigenotoxic properties of aqueous extract of $N$. sativa $79.5 \mu \mathrm{g} / \mathrm{mL}$ were tested in F344 hepatocytes treated with $N$-methyl- $N$-nitro- $N$-nitrosoguanidine (MNNG); results showed that $N$. sativa could not protect hepatocytes from the clastogenic effect of MNNG and produced a remarkable increase of chromosomal aberrations when used as a pretreatment. The findings revealed that this extract displayed a small, but significant, genotoxic potential [59].

Based on the cytotoxic studies, we concluded that the ethanolic extract and aqueous extract of $N$. sativa are safer than other extracts in different cell lines. Essential oil and volatile oil of $N$. sativa are relatively safe.

Table 5 summarizes studies in vitro [57-59, 67-70, 72-74] that evaluated cytotoxicity and genotoxicity of N. sativa.

Table 5. Cytotoxic and genotoxic properties of Nigella sativa in vitro

\begin{tabular}{|c|c|c|c|c|c|}
\hline Substance & Concentration period & Period & Cell type & Main results & Reference \\
\hline N. sativa oil & $0.25,0.5$, and $1 \mu \mathrm{g} / \mathrm{mL}$ & $95 \mathrm{~h}$ & Gingival fibroblasts & No cytotoxicity & {$[67]$} \\
\hline N. sativa $\mathrm{EE}$ & $0-2 \mathrm{mg} / \mathrm{mL}$ & $24 \mathrm{~h}$ & $\begin{array}{l}\text { Rat L6 muscle cell line } \\
\text { HepG2 cell line }\end{array}$ & $\begin{array}{l}\mathrm{EC}_{50}>2,000 \mu \mathrm{g} / \mathrm{mL} \text { against L6myc } \\
\text { cell lines } \\
\mathrm{EC}_{50}>1,470 \mu \mathrm{g} / \mathrm{mL} \text { against HepG2 } \\
\text { cell lines }\end{array}$ & [68] \\
\hline N. sativa $\mathrm{EE}$ & 100,500, and $1,000 \mu \mathrm{g} / \mathrm{mL}$ & $48 \mathrm{~h}$ & Isolated rat splenocytes & $\begin{array}{l}\text { Cytotoxic effects at } 500 \text { and } \\
1,000 \mu \mathrm{g} / \mathrm{mL}\end{array}$ & {$[57]$} \\
\hline $\begin{array}{l}\text { N. sativa } \mathrm{EO} \text { and } \\
\mathrm{ME}, \mathrm{PE}, \mathrm{CE}, \mathrm{AE} \text {, and } \\
\text { ether extract }\end{array}$ & 10,100, and $1,000 \mu \mathrm{g} / \mathrm{mL}$ & $24 \mathrm{~h}$ & BSL & $\begin{array}{l}\text { Higher toxicity by chloroform and } \\
\text { petroleum ether extracts. } \\
\mathrm{LC}_{50} \text { petroleum ether: } 7 \mu \mathrm{g} / \mathrm{mL} \\
\mathrm{LC}_{50} \text { chloroform: } 21 \mu \mathrm{g} / \mathrm{mL}\end{array}$ & [69] \\
\hline N. sativa seed VO & $500,250,125$, and $62.5 \mu \mathrm{g} / \mathrm{mL}$ & Not specified & $\begin{array}{l}\text { SCL, SCL-6, SCL-37'6, } \\
\text { NUGC-4, Kato-3, 3T6 }\end{array}$ & $\begin{array}{l}\mathrm{LC}_{50} \mathrm{SCL} 155.02 \mu \mathrm{g} / \mathrm{mL} \\
\mathrm{LC}_{50} \mathrm{SCL}-6185.77 \mu \mathrm{g} / \mathrm{mL} \\
\mathrm{LC}_{50} \mathrm{SCL}-37^{\prime} 6120.40 \mu \mathrm{g} / \mathrm{mL} \\
\mathrm{LC}_{50} \mathrm{NUGC}-4384.53 \mu \mathrm{g} / \mathrm{mL} \\
\mathrm{LC}_{50} 3 \mathrm{~T} 6286.83 \mu \mathrm{g} / \mathrm{mL}\end{array}$ & {$[70]$} \\
\hline N. sativa $\mathrm{PE}$ and $\mathrm{AE}$ & $670 \mu \mathrm{g} / \mathrm{mL}$ & $24 \mathrm{~h}$ & HL60 & $\begin{array}{l}\mathrm{IC}_{50} \mathrm{PE} 654 \mu \mathrm{g} / \mathrm{mL} \\
\mathrm{IC}_{50} \mathrm{AE}>1,000 \mu \mathrm{g} / \mathrm{ml}\end{array}$ & [71] \\
\hline N. sativa EO & $100 \mathrm{mg} / \mathrm{mL}$ & $24 \mathrm{~h}$ & Huh7 human cells & No cytotoxicity & {$[72]$} \\
\hline N. sativa seed oil & $50-500 \mu \mathrm{g} / \mathrm{mL}$ & & $\begin{array}{l}\text { U-1242, U251, U-87, U-373, } \\
\text { A172 and SNB19 }\end{array}$ & $\mathrm{IC}_{50} 260 \mu \mathrm{g} / \mathrm{mL}$ & {$[58]$} \\
\hline AE of $N$. sativa & $0.5,1,4,8,9$, and $18 \mathrm{mg} / \mathrm{mL}$ & & Human C 3 A cells & $\begin{array}{l}\text { Positive micronucleus test extract } \\
\text { from Setta }\end{array}$ & [73] \\
\hline $\begin{array}{l}\text { N. sativa seed } M E \text {, } \\
N E \text {, and } C E\end{array}$ & $\begin{array}{l}2,2.25,2.5,2.75 \text {, and } 3 \mu \mathrm{g} / \mathrm{mL} \\
\text { of methanolic, } \mathrm{n} \text {-hexane. } \\
0.25,0.5,0.75 \text {, and } 1 \mathrm{ng} / \mathrm{mL} \text { of } \\
\text { chloroform }\end{array}$ & $24 \mathrm{~h}$ & HeLa cells & $\begin{array}{l}\mathrm{IC}_{50} \text { methanolic: } 2.28 \mu \mathrm{g} / \mathrm{mL} \\
\mathrm{IC}_{50} \mathrm{n} \text {-hexane } 2.20 \mu \mathrm{g} / \mathrm{mL} \\
\mathrm{IC}_{50} \text { chloroform } 0.41 \mathrm{ng} / \mathrm{mL}\end{array}$ & {$[74]$} \\
\hline N. sativa AE & $79.5 \mu \mathrm{g} / \mathrm{mL}$ & $48 \mathrm{~h}$ & $\begin{array}{l}\text { F } 344 \text { hepatocytes treated } \\
\text { with MNNG }\end{array}$ & $\uparrow$ Chromosomal aberrations & [59] \\
\hline
\end{tabular}

VO, volatile oil; $\mathrm{FO}$, fixed oil; $\mathrm{AE}$, aqueous extract; $\mathrm{ME}$, methanol extract; $\mathrm{CE}$, chloroform extract; $\mathrm{NE}$, $n$-hexane extract; $E \mathrm{E}$, essential oil; $\mathrm{EE}$, ethanol extract; $\mathrm{PE}$, petroleum ether extract; $\mathrm{EC}_{50^{\prime}}$ effective concentration; $\mathrm{BSL}$, brine shrimp lethality assay; $\mathrm{LC}_{50^{\prime}}$ concentration that kills $50 \%$ of the cells, $I C_{50}$, half-maximal inhibitory concentration inhibits 50\% cell maximal growth; HL60, human myeloid leukemia cell line; $M N N G, N$-methyl$N$-nitro- $N$-c. 


\section{N. sativa toxicity in humans}

Administration of $N$. sativa oil to human volunteers at $5 \mathrm{~mL} /$ day for 26 days produced no significant hepatic, renal, or gastrointestinal adverse effects $[75,76]$. N. sativa seeds (3 g/day for 3 months) consumed by 39 centrally obese subjects did not lead to marked side effects [77]. Similarly, diabetic patients who took $N$. sativa seeds $(1,2$, and $3 \mathrm{~g} /$ day for 3 months) showed no significant alterations in renal or hepatic function [18]. However, epigastric pain and hypoglycemia were observed in hepatitis $\mathrm{C}$ virus patients treated with $N$. sativa seed oil capsules [38]. The use of total oil was associated with a marked increase of blood levels of AST and ALT and both the oil and the crushed seeds resulted in significantly increased $\gamma$-GT and the ALP activities [78]. N. sativa seeds (5 g/day) had an inhibitory effect on CYP2D6 and CYP3A4 in human liver microsomes and healthy human volunteers [79].

A 28-year-old man who had used pure oil of black cumin topically on his neck for 3 months as a treatment of sore throat, presented with a 2-day history of maculopapular eczema, first on the neck and spreading to his arms and back. To our knowledge, this was the first documented case of allergic contact dermatitis caused by topical black cumin oil [60].

A 31-year-old woman with an 8-month history of eczema on both hands and exacerbation of the skin lesions repeatedly applied an ointment containing essential oil extracted from the seeds of black cumin to her palms as a skin-care product. A biopsy from the left hypothenar showed signs of subacute dermatitis. Patch tests showed reactions to the ointment of black cumin in the form of allergic contact dermatitis [61].

A 56-year-old woman presented a 2-day history of severe bullous target-like lesions, compatible with erythema multiform. Histopathology of the lesions indicated lymphocytic infiltration at the dermal-epidermal junction, dermal edema, basal vacuolization, and keratinocyte necrosis.
During the last 15 days before the eruption, she had been taking 2 capsules of black cumin essential oil, containing $500 \mathrm{mg}$ of organic $N$. sativa oil (and $7.5 \mathrm{mg}$ of vitamin E) per day. These reactions (presented in Table 6), based on previous reports $[60,61,80]$, should alert physicians to be informed of potentially intense adverse effects of $N$. sativa essential oils [80].

Clinical trials that examined $N$. sativa and its active constituent, thymoquinone, found these agents safe, but notably several adverse effects such as bloating, nausea, and burning sensation were observed in functionally dyspeptic patients treated with $N$. sativa oil. Moreover, after using $N$. sativa oil and crushed seeds, a slight increase in kidney and liver enzymes was observed [81].

Our literature review to retrieve studies conducted on the short- and long-term toxic effects of $N$. sativa oils and extracts showed that a considerable number of studies were conducted without characterizing the plant material or its extracts; moreover, studies simultaneously in both sexes, in animals other than rats or mice, or performed to provide a full toxicological screening of all parameters of importance, are lacking. Dose ranges vary among studies making it difficult to draw conclusions.

\section{Conclusions}

The essential oil obtained from $N$. sativa was found to be safer than the volatile oil against different cell lines. Human case reports indicated allergic contact dermatitis following the use of some preparations containing $N$. sativa. However, clinical trials did not report any severe adverse effects following consumption $N$. sativa. Studies that assessed $N$. sativa safety generally introduced this plant as a safe medicinal herb. Nevertheless, more detailed investigations are still required to have a clearer insight into the toxicological profile of N. sativa.

Table 6. Nigella sativa toxicity in humans

\begin{tabular}{|c|c|c|c|c|c|}
\hline Substance & Concentration & Exposure route/period & Case history & Main results & Reference \\
\hline Pure oil of black cumin & Not specified & $\begin{array}{l}\text { Used on the neck for } \\
3 \text { months }\end{array}$ & $\begin{array}{l}\text { 28-year-old man for } \\
\text { treatment of sore throat }\end{array}$ & $\begin{array}{l}\text { Allergic contact } \\
\text { dermatitis }\end{array}$ & {$[60]$} \\
\hline $\begin{array}{l}\text { EO of the seeds of black } \\
\text { cumin }\end{array}$ & Not specified & $\begin{array}{l}\text { Repeatedly applied as an } \\
\text { ointment }\end{array}$ & $\begin{array}{l}\text { 31-year-old woman with } \\
\text { an 8-month history of } \\
\text { eczema on both hands }\end{array}$ & $\begin{array}{l}\text { Allergic contact } \\
\text { dermatitis }\end{array}$ & {$[61]$} \\
\hline Capsules of BCEO & $\begin{array}{l}\text { Containing } 500 \mathrm{mg} \text { of } \\
\text { organic } N \text {. sativa oil and } \\
7.5 \mathrm{mg} \text { of vitamin } \mathrm{E}\end{array}$ & $\begin{array}{l}\text { Daily } \\
15 \text { days }\end{array}$ & 56-year-old woman & $\begin{array}{l}\text { Severe bullous target-like } \\
\text { lesions, compatible with } \\
\text { erythema multiforme }\end{array}$ & {$[80]$} \\
\hline
\end{tabular}

EO, essential oil. 
Author contributions. GK and RR made substantial contributions to the conception and design of this review. HM-S and RR collected and analyzed the data. All authors contributed to the original draft, and GK and RR critically revised it. All authors approved the final version submitted for publication and take responsibility for statements made in the published article.

Acknowledgment. This work was supported by grant 484 from the Mashhad University of Medical Sciences awarded to Gholamreza Karimi.

Conflicts of interest statement. The authors have each completed and submitted an International Committee of Medical Journal Editors Uniform Disclosure Form for Potential Conflicts of Interest. None of the authors has any potential or actual conflict of interest to disclose concerning the published article.

Data sharing statement. No new data sets were generated or analyzed during the present study. The present review is based on the references cited.

\section{References}

[1] Gali-Muhtasib H, Roessner A, Schneider-Stock R. Thymoquinone: a promising anti-cancer drug from natural sources. Int J Biochem Cell Biol. 2006; 38:1249-53.

[2] Ansari Z, Satish T. Traditional uses of Nigella sativa, in Malegaon region of Nashik - a review. Int J Pure App Biosci. 2013; 1:19-23.

[3] Nadkarni KM (Krishnarao Mangeshrao), Nadkarni AK. Dr. K. M. Nadkarni's Indian materia medica, with ayurvedic, unani-tibbi, siddha, allopathic, homeopathic, naturopathic and home remedies, appendices and indexes. 3rd ed. Bombay: Popular Prakashan; 1954 [cited 2020 Feb 02] Available from: https://trove.nla.gov.au/version/21887031

[4] Vahdati-Mashhadian N, Rakhshandeh H, Omidi A. An investigation on LD50 and subacute hepatic toxicity of Nigella sativa seed extracts in mice. Pharmazie. 2005; 60:544-7.

[5] Forouzanfar F, Bazzaz BSF, Hosseinzadeh H. Black cumin (Nigella sativa) and its constituent (thymoquinone): a review on antimicrobial effects. Iran J Basic Med Sci. 2014; 17:929-38.

[6] Majdalawieh AF, Fayyad MW. Recent advances on the anti-cancer properties of Nigella sativa, a widely used food additive. J Ayurveda Integr Med. 2016; 7:173-80.

[7] Mahmoud YK, Abdelrazek HMA. Cancer: Thymoquinone antioxidant/pro-oxidant effect as potential anticancer remedy. Biomed Pharmacother. 2019; 115:108783. doi: 10.1016/j. biopha.2019.108783

[8] Majdalawieh AF, Fayyad MW. Immunomodulatory and anti-inflammatory action of Nigella sativa and thymoquinone: a comprehensive review. Int Immunopharmacol. 2015; 28:295-304.

[9] Hosseinian S, Roshan NM, Khazaei M, Shahraki S, Mohebbati R, Rad AK. Renoprotective effect of Nigella sativa against cisplatin- induced nephrotoxicity and oxidative stress in rat. Saudi J Kidney Dis Transpl. 2018; 29:19-29.

[10] Şen N, Kar Y, Tekeli Y. Antioxidant activities of black cumin (Nigella sativa L.) seeds cultivating in different regions of Turkey. J Food Biochem. 2010; 34:105-19.

[11] Boskabady M-H, Keyhanmanesh R, Khameneh S, Doostdar Y, Khakzad M-R. Potential immunomodulation effect of the extract of Nigella sativa on ovalbumin sensitized guinea pigs. J Zhejiang Univ Sci B. 2011; 12:201-9.

[12] Ramadhan UH, Mohammedali MA, Abood HS. Study the analgesic activity of Nigella sativa L. volatile oil against pain in mice. J Curr Pharm Res. 2011; 5:36-8.

[13] Tuna HI, Babadag B, Ozkaraman A, Balci Alparslan G. Investigation of the effect of black cumin oil on pain in osteoarthritis geriatric individuals. Complement Ther Clin Pract. 2018; 31:290-4.

[14] Zakaria A, Jais MR, Ishak R. Analgesic properties of Nigella Sativa and Eucheuma Cottonii extracts. J Nat Sci Biol Med. 2018; 9:23-26.

[15] Asif M, Jabeen Q, Majid A, Atif M. Diuretic activity of aqueous extract of Nigella sativa in albino rats. Acta Pol Pharm. 2015; 72:129-35

[16] Benhelima A, Kaid-Omar Z, Hemida H, Benmahdi T, Addou A. Nephroprotective and diuretic effect of Nigella sativa L. seeds oil on lithiasic Wistar rats. Afr J Tradit Complement Altern Med. 2016; 13:204-14

[17] Jaarin K, Foong WD, Yeoh MH, Kamarul ZYN, Qodriyah HMS, Azman A, et al. Mechanisms of the antihypertensive effects of Nigella sativa oil in L-NAME-induced hypertensive rats. Clinics. 2015; 70:751-7.

[18] Bamosa AO, Kaatabi H, Lebdaa FM, Elq A, Al-Sultanb A. Effect of Nigella sativa seeds on the glycemic control of patients with type 2 diabetes mellitus. Indian J Physiol Pharmacol. 2010; 54:344-54.

[19] El Rabey HA, Al-Seeni MN, Bakhashwain AS. The antidiabetic activity of Nigella sativa and propolis on streptozotocininduced diabetes and diabetic nephropathy in male rats. Evid Based Complement Alternat Med. 2017; 2017:5439645. doi: 10.1155/2017/5439645

[20] Abdelrazek HMA, Kilany OE, Muhammad MAA, Tag HM, Abdelazim AM. Black seed thymoquinone improved insulin secretion, hepatic glycogen storage, and oxidative stress in streptozotocin-induced diabetic male Wistar rats. Oxid Med Cell Longev. 2018; 2018:8104165. doi: 10.1155/2018/8104165

[21] Kanter M, Demir H, Karakaya C, Ozbek H. Gastroprotective activity of Nigella sativa L. oil and its constituent, thymoquinone against acute alcohol-induced gastric mucosal injury in rats. World J Gastroenterol. 2005; 11:6662-6.

[22] Shakeri F, Gholamnezhad Z, Mégarbane B, Rezaee R, Boskabady $\mathrm{MH}$. Gastrointestinal effects of Nigella sativa and its main constituent, thymoquinone: a review. Avicenna J Phytomed. 2016; 6:9-20.

[23] Al-Seeni MN, El Rabey HA, Zamzami MA, Alnefayee AM. The hepatoprotective activity of olive oil and Nigella sativa oil against $\mathrm{CCl}_{4}$ induced hepatotoxicity in male rats. BMC Complement Altern Med. 2016; 16:438. doi: 10.1186/s12906-016-1422-4

[24] Sayeed MSB, Asaduzzaman M, Morshed H, Hossain MM, Kadir MF, Rahman MR. The effect of Nigella sativa Linn. seed on memory, attention and cognition in healthy human volunteers. J Intercult Ethnopharmacol. 2013; 148:780-6.

[25] Shawki M, El Wakeel L, Shatla R, Gamila E-S, Ibrahim S, Badary O. The clinical outcome of adjuvant therapy with black seed oil on 
intractable paediatric seizures: a pilot study. Epileptic Disord. 2013; 15:295-301.

[26] Sayeed MSB, Shams T, Hossain SF, Rahman MR, Mostofa A, Kadir $\mathrm{MF}$, et al. Nigella sativa $\mathrm{L}$. seeds modulate mood, anxiety and cognition in healthy adolescent males. J Intercult Ethnopharmacol. 2014; 152:156-62.

[27] Dehkordi FR, Kamkhah AF. Antihypertensive effect of Nigella sativa seed extract in patients with mild hypertension. Fundam Clin Pharmacol. 2008; 22:447-52.

[28] Rizka A, Setiati S, Lydia A, Dewiasty E. Effect of Nigella sativa seed extract for hypertension in elderly: a double-blind, randomized controlled trial. Acta Med Indones. 2017; 49:307-13.

[29] Majeed A, Naveed AK. Comparative evaluation of Nigella sativa (Kalonji) and simvastatin for the treatment of hyperlipidemia and in the induction of hepatotoxicity. Pak J Pharm Sci. 2015; 28:493-8.

[30] Sabzghabaee AM, Dianatkhah M, Sarrafzadegan N, Asgary S, Ghannadi A. Clinical evaluation of Nigella sativa seeds for the treatment of hyperlipidemia: a randomized, placebo controlled clinical trial. Med Arch. 2012; 66:198-200.

[31] Mahdavi R, Namazi N, Alizadeh M, Farajnia S. Effects of Nigella sativa oil with a low-calorie diet on cardiometabolic risk factors in obese women: a randomized controlled clinical trial. Food Funct. 2015; 6:2041-8.

[32] Mousavi SM, Sheikhi A, Varkaneh HK, Zarezadeh M, Rahmani J, Milajerdi A. Effect of Nigella sativa supplementation on obesity indices: a systematic review and meta-analysis of randomized controlled trials. Complement Ther Med. 2018; 38:48-57.

[33] Gheita TA, Kenawy SA. Effectiveness of Nigella sativa oil in the management of rheumatoid arthritis patients: a placebo controlled study. Phytother Res. 2012; 26:1246-8.

[34] Hadi V, Kheirouri S, Alizadeh M, Khabbazi A, Hosseini H. Effects of Nigella sativa oil extract on inflammatory cytokine response and oxidative stress status in patients with rheumatoid arthritis: a randomized, double-blind, placebo-controlled clinical trial. Avicenna J Phytomed. 2016; 6:34-43.

[35] Kheirouri S, Hadi V, Alizadeh M. Immunomodulatory effect of Nigella sativa oil on $\mathrm{T}$ lymphocytes in patients with rheumatoid arthritis. Immunol Invest. 2016; 45:271-83.

[36] Koshak A, Wei L, Koshak E, Wali S, Alamoudi O, Demerdash A, et al. Nigella sativa supplementation improves asthma control and biomarkers: a randomized, double-blind, placebo-controlled trial. Phytother Res. 2017; 31:403-9.

[37] Farhangi MA, Dehghan P, Tajmiri S, Abbasi MM. The effects of Nigella sativa on thyroid function, serum vascular endothelial growth factor (VEGF) - 1, Nesfatin-1 and anthropometric features in patients with Hashimoto's thyroiditis: a randomized controlled trial. BMC Complement Med Ther. 2016; 16:471. doi: 10.1186/ s12906-016-1432-2.

[38] Barakat EMF, El Wakeel LM, Hagag RS. Effects of Nigella sativa on outcome of hepatitis C in Egypt. World J Gastroenterol. 2013; 19:2529-36.

[39] Mahdavi R, Heshmati J, Namazi N. Effects of black seeds (Nigella sativa) on male infertility: a systematic review. J Herb Med. 2015; 5:133-9.

[40] Ahmad A, Husain A, Mujeeb M, Khan SA, Najmi AK, Siddique NA, et al. A review on therapeutic potential of Nigella sativa: a miracle herb. Asian Pac J Trop Biomed. 2013; 3:337-52.

[41] Benkaci-Ali F, Baaliouamer A, Meklati BY, Chemat F. Chemical composition of seed essential oils from Algerian Nigella sativa extracted by microwave and hydrodistillation. Flavour Frag J. 2007; 22:148-53.

[42] Tembhurne S, Feroz S, More B, Sakarkar D. A review on therapeutic potential of Nigella sativa (kalonji) seeds. J Med Plant Res. 2014; 8:167-77.

[43] Ali B, Blunden G. Pharmacological and toxicological properties of Nigella sativa. Phytother Res. 2003; 17:299-305.

[44] Hamburger M, Hostettmann K. Bioactivity in plants: the link between phytochemistry and medicine. Phytochemistry. 1991; 30:3864-74.

[45] El-Dakhakhny M. Studies on the chemical constitution of Egyptian Nigella sativa L. seeds. II) The essential oil. Planta Med. 1963; 11:465-70.

[46] Hosseinzadeh H, Parvardeh S. Anticonvulsant effects of thymoquinone, the major constituent of Nigella sativa seeds, in mice. Phytomedicine. 2004; 11:56-64.

[47] Mashayekhi-Sardoo H, Rezaee R, Karimi G. An overview of in vivo toxicological profile of thymoquinone. Toxin Rev. 2020; 39:115-122.

[48] Zaghlol DAA, Kamel ES, Mohammed DS, Abbas NH. The possible toxic effect of different doses of Nigella sativa oil on the histological structure of the liver and renal cortex of adult male albino rats. Egypt J Histol. 2012; 35:127-36.

[49] Zaoui A, Cherrah Y, Mahassini N, Alaoui K, Amarouch H, Hassar M. Acute and chronic toxicity of Nigella sativa fixed oil. Phytomedicine. 2002; 9:69-74.

[50] Bolton JL, Trush MA, Penning TM, Dryhurst G, Monks TJ. Role of quinones in toxicology. Chem Res Toxicol. 2000; 13:135-60.

[51] El-Hadiyah T, Raza M, Mohammed O, Abdallah A. Evaluation of Nigella sativa seed constituents for their in vivo toxicity in mice. Nat Prod Sci. 2003; 9:22-7.

[52] Yu S-M, Kim S-J. The thymoquinone-induced production of reactive oxygen species promotes dedifferentiation through the ERK pathway and inflammation through the $\mathrm{p} 38$ and PI3K pathways in rabbit articular chondrocytes. Int J Mol Med. 2015; 35:325-32.

[53] Khanna T, Zaidi F, Dandiya P. CNS and analgesic studies on Nigella sativa. Fitoterapia. 1993; 5:407-10.

[54] Al-Jishi S, Hozaifa BA. Effect of Nigella sativa on blood hemostatic function in rats. J Ethnopharmacol. 2003; 85:7-14.

[55] Al-Homidan A, Al-Qarawi AA, Al-Waily SA, Adam SEI. Response of broiler chicks to dietary Rhazya stricta and Nigella sativa. $\mathrm{Br}$ Poult Sci. 2002; 43:291-6.

[56] Zaoui A, Cherrah Y, Alaoui K, Mahassine N, Amarouch H, Hassar M. Effects of Nigella sativa fixed oil on blood homeostasis in rat. J Ethnopharmacol. 2002; 79:23-6.

[57] Gholamnezhad Z, Rafatpanah H, Sadeghnia HR, Boskabady MH. Immunomodulatory and cytotoxic effects of Nigella sativa and thymoquinone on rat splenocytes. Food Chem Toxicol. 2015; 86:72-80.

[58] Hussaini IM, Amos S, Simpson K, Redpath GT, Lyons C, Dipierro C. Nigella sativa and thymoquinone induce caspase-9/3 activation and glioblastoma cell death. In: Preclinical experimental therapeutics and pharmacology. ET-20. Abstracts from the 16th Annual Scientific Meeting of the Society for Neuro-Oncology in Conjunction with the AANS/CNS Section on Tumors; 2011 November 17-20, Orange County, California. Oxford: Oxford University Press on behalf of the Society for Neuro-Oncology. Neuro-Oncol. 2011; 13(Suppl 3):iii111. [abstract]

[59] Khader M, Eckl P, Bresgen N. Effects of aqueous extracts of medicinal plants on MNNG-treated rat hepatocytes in primary cultures. J Ethnopharmacol. 2007; 112:199-202. 
[60] Steinmann A, Schätzle M, Agathos M, Brett R. Allergic contact dermatitis from black cumin (Nigella sativa) oil after topical use. Contact Dermatitis. 1997; 36:268-9.

[61] Zedlitz S, Kaufmann R, Boehncke WH. Allergic contact dermatitis from black cumin (Nigella sativa) oil-containing ointment. Contact Dermatitis. 2002; 46:188.

[62] Amina B. Toxicity and anti-oxidant activity of the essential oil of Nigella sativa. Pharm Lett. 2016; 8:245-9.

[63] Tennekoon KH, Jeevathayaparan S, Kurukulasooriya AP, Karunanayake EH. Possible hepatotoxicity of Nigella sativa seeds and Dregea volubilis leaves. J Ethnopharmacol. 1991; 31:283-9.

[64] Dollah MA, Parhizkar S, Latiff LA, Hassan MHB. Toxicity effect of Nigella sativa on the liver function of rats. Adv Pharm Bull. 2013; 3:97-102.

[65] Bensiameur-Touati K, Kacimi G, Haffaf E-M, Berdja S, AouichatBouguerra S. In vivo subacute toxicity and antidiabetic effect of aqueous extract of Nigella sativa. Evid Based Complement Alternat Med. 2017; 2017:8427034. doi: 10.1155/2017/8427034

[66] Lou WP, Assaw S, Lokman MA, Suhaimin N, Yusof HM. Sub-acute toxicity of black seed (Nigella sativa) and honey mixture. Malays Appl Biol. 2018; 47:11-8.

[67] Ugur AR, Dagi HT, Ozturk B, Tekin G, Findik D. Assessment of in vitro antibacterial activity and cytotoxicity effect of Nigella sativa oil. Phcogn Mag. 2016; 12(Suppl 4):S471-4.

[68] Kadan S, Saad B, Sasson Y, Zaid H. In vitro evaluations of cytotoxicity of eight antidiabetic medicinal plants and their effect on GLUT4 translocation. Evid Based Complement Altern Med. 2013; 2013:549345. doi: 10.1155/2013/549345.

[69] Mahmoudvand H, Sharififar F, Assadipour A, Hassan Moshafi $\mathrm{M}$, Alishahi F. Bioassay screening of the essential oil and various extracts of Nigella sativa L. seeds using brine shrimp toxicity assay. J Herb Med. 2017; 2:26-31.

[70] Nazrul Islam S, Begum P, Ahsan T, Huque S, Ahsan M. Immunosuppressive and cytotoxic properties of Nigella sativa. Phytother Res. 2004; 18:395-8.

[71] Norfazlina MN, Farida Zuraina MY, Rajab NF, Mohd Nazip S, Rumiza AR, Suziana Zaila CF, et al. Cytotoxicity study of Nigella sativa and Zingiber zerumbet extracts, thymoquinone and zerumbone isolated on human myeloid leukemia (HL60) cell. Open Conf Proc J. 2013; 4(Suppl 2, M16):99-107.

[72] Panah KH, Ghasemi Fe, Hosseini SM, Zojaji SA, Meshkat Z. Evaluation of the toxic effects of Nigella sativa on human cell lines of hepatic origin. Avicenna J Phytomed. 2015; 5:87-8.

[73] Nguyen T, Talbi H, Hilali A, Anthonissen R, Maes A, Verschaeve L. In vitro toxicity, genotoxicity and antigenotoxicity of Nigella sativa extracts from different geographic locations. S Afr J Bot. 2019; 126:132-41.

[74] Shafi G, Munshi A, Hasan TN, Alshatwi AA, Jyothy A, Lei DKY. Induction of apoptosis in HeLa cells by chloroform fraction of seed extracts of Nigella sativa. Cancer Cell Int. 2009; 9:29. doi: 10.1186/1475-2867-9-29

[75] Amini M, Fallah Huseini H, Mohtashami R, Sadeqhi Z, Ghamarchehre M. Hypolipidemic effects of Nigella sativa L. seeds oil in healthy volunteers: a randomized, double-blind, placebocontrolled clinical trial. J Med Plant. 2011; 4:133-8.

[76] Fallah Huseini H, Amini M, Mohtashami R, Ghamarchehre M, Sadeqhi Z, Kianbakht S, Fallah Huseini, A. Blood pressure lowering effect of Nigella sativa L. seed oil in healthy volunteers: a randomized, double-blind, placebo-controlled clinical trial. Phytother Res. 2013; 27:1849-53.

[77] Datau E, Surachmanto E, Pandelaki K, Langi J. Efficacy of Nigella sativa on serum free testosterone and metabolic disturbances in central obese male. Acta Med Indones. 2010; 42:130-4.

[78] Ibraheim ZZ. Effect of Nigella sativa seeds and total oil on some blood parameters in female volunteers. Saudi Pharm J. 2002; 10:54-9.

[79] Al-Jenoobi FI, Al-Thukair AA, Abbas FA, Ansari MJ, Alkharfy KM, Al-Mohizea AM, et al. Effect of black seed on dextromethorphan $\mathrm{O}$ - and N-demethylation in human liver microsomes and healthy human subjects. Drug Metab Lett. 2010; 4:51-5.

[80] Nosbaum A, Said BB, Halpern S-J, Nicolas J-F, Bérard F. Systemic allergic contact dermatitis to black cumin essential oil expressing as generalized erythema multiforme. Eur J Dermatol. 2011; 21:447-8.

[81] Tavakkoli A, Mahdian V, Razavi BM, Hosseinzadeh H. Review on clinical trials of black seed (Nigella sativa) and its active constituent, thymoquinone. J Pharmacopuncture. 2017; 20:179-93. 